\title{
Koniec dominacji wielkich partii? System partyjny RFN po zjednoczeniu Bilans 25 lat
}

Przeprowadzone w 1990 roku ponowne zjednoczenie Niemiec oznaczało w praktyce włączenie nowych krajów z byłej Niemieckiej Republiki Demokratycznej do systemu politycznego Republiki Federalnej Niemiec. Również mechanizmy rządzące zachodnioniemieckim systemem partyjnym zostały rozciągnięte na Niemcy wschodnie, a większość wschodnioniemieckich ugrupowań politycznych została wchłonięta przez siostrzane partie z zachodu Niemiec. Zmienił się za to format systemu partyjnego RFN poprzez dołączenie Partii Demokratycznego Socjalizmu (Partei des Demokratischen Sozialismus, PDS), partii reprezentującej interesy przede wszystkim mieszkańców Niemiec wschodnich, rozczarowanych przemianami po 1990 roku. Na scenie politycznej zjednoczonych Niemiec nadal dominowały tradycyjne partie zachodnioniemieckie - CDU/CSU, SPD, FDP i Zieloni (od 1993 roku Sojusz 90/Zieloni) - a PDS do 2005 roku balansowała na granicy progu wyborczego. Po 1990 roku system partyjny RFN ewoluował w stronę systemu złożonego z pięciu partii ${ }^{1}$ relewantnych reprezentowanych $\mathrm{w}$ Bundestagu, by osiągnąć taki status po 2005 roku, gdy PDS udało się znaleźć partnera na zachodzie Niemiec (w latach 2005-2007 jako sojusz Linkspartei.PDS, od 2007 roku jako nowa partia Die Linke).

Ważnym następstwem zjednoczenia było wytworzenie się na obszarze byłej NRD dość specyficznego podsystemu partyjnego zdominowanego przez trzy duże partie (CDU, SPD i PDS), jak również ujawniające się w kolejnych

1 W rozważaniach dotyczących systemu partyjnego siostrzane partie CDU i CSU będą traktowane jako jedna partia. 
wyborach różnice $\mathrm{w}$ preferencjach wyborczych pomiędzy Niemcami ze Wschodu i Zachodu. Po zjednoczeniu wzrosła dynamika zmian na niemieckiej scenie politycznej. Z jednej strony nastąpiło stopniowe osłabienie pozycji obu wielkich partii tzw. Volksparteien (CDU/CSU i przede wszystkim SPD), co doprowadziło do powstania tezy o końcu dominacji dwóch wielkich partii na niemieckiej scenie politycznej, z drugiej strony wzrosło znaczenie partii średnich i pojawił się szereg nowych ugrupowań, często antysystemowych, z których niektóre (partie skrajnej prawicy, partia Schilla, Partia Piratów, AfD) potrafiły odnosić spore sukcesy w wyborach do parlamentów krajowych. Zjawiska te zostaną poddane szerszej analizie w dalszej części artykułu. Na zakończenie omówiony zostanie wpływ kryzysu migracyjnego na sondażowe notowania niemieckich partii politycznych od jesieni 2015 roku do wiosny 2016 roku.

Zachodnioniemiecki system partyjny uformował się pod koniec lat 40. i na początku lat 50. XX wieku pod wpływem demokratyzacji narzuconej Niemcom przez mocarstwa zachodnie po klęsce III Rzeszy. Po 1945 roku życie polityczne odradzało się we wszystkich czterech strefach okupacyjnych pod ścisłą kontrolą Aliantów, a niemieckie partie polityczne mogły działać w oparciu o tzw. licencje, które zniesiono dopiero w 1950 roku. W tym okresie powstały lub odrodziły się trzy główne siły polityczne późniejszej RFN: chadecja, SPD i FDP. Unia Chrześcijańsko-Demokratyczna (i jej siostrzana bawarska Unia Chrześcijańsko-Społeczna) była partią nową, integrującą w sobie działaczy z różnych środowisk centrum i prawej strony sceny politycznej - działaczy katolickich i protestanckich, ale również liberałów i konserwatystów - kierującą się wartościami chrześcijańskimi i propagującą idee społecznej gospodarki rynkowej. Zdaniem Ulricha von Alemanna utworzenie CDU było „prawdziwą innowacją w dziejach niemieckich partii politycznych po drugiej wojnie światowej"2. Po dwunastu latach pracy na emigracji działalność na ziemiach niemieckich wznowiła w 1945 roku Socjaldemokratyczna Partia Niemiec, a jej pierwszym przewodniczącym został Kurt Schumacher.

Na przełomie lat 40. i 50. SPD była typową partią masową reprezentującą przede wszystkim interesy robotników. SPD pozostawała wówczas w głębokiej opozycji wobec rządów Konrada Adenauera i jednoznacznie sprzeciwiała się podziałowi Niemiec na dwa odrębne państwa. Po 1945 roku na szczeblu lokalnym odradzały się i tworzyły się również inne partie, w tym

2 U. von Alemann, Das Parteiensystem der Bundesrepublik Deutschland, Bonn 2010, s. 53; P. Kubiak, System partyjny i partie polityczne zjednoczonych Niemiec (19902013), Poznań 2014, s. 32. 
ugrupowania liberalne. Na zjeździe liberałów w Heppenheim (11/12 grudnia 1948 roku) powołano do życia wspólną partię - Wolną Partię Demokratyczną (Freie Demokratische Partei, FDP) ${ }^{3}$ - łączącą w sobie oba nurty niemieckiego liberalizmu, tj. lewicowy (socjalny) i narodowo-liberalny, kończąc w ten sposób ponad 80-letni okres podziału niemieckiego obozu liberalnego. Te trzy partie stanowily filary zachodnioniemieckiego systemu partyjnego w latach 1949-1989. Ramy funkcjonowania niemieckich partii politycznych zostały ściśle określone na podstawie zapisów Ustawy Zasadniczej (art. 21), orzeczeń Federalnego Trybunału Konstytucyjnego i wielokrotnie nowelizowanej ustawy o partiach politycznych z 1967 roku. Partiom politycznym wyznaczono rolę pośrednika w kształtowaniu woli politycznej narodu, co w praktyce oznaczało, że w państwie demokratycznym, jakim stała się Republika Federalna Niemiec, władza znalazła się w rękach partii politycznych reprezentujących interesy społeczeństwa ${ }^{4}$. Utwierdziła się w ten sposób idea państwa partii (der Parteienstaat). Ważnym elementem wpływającym na specyfikę zachodnioniemieckiego systemu partyjnego była mieszana ordynacja wyborcza do Bundestagu (i ordynacje do parlamentów krajowych), łącząca w sobie elementy ordynacji większościowej z proporcjonalną poparte 5-procentową klauzulą zaporową (Sperrklausel).

Wszystkie te elementy - zarówno ramy instytucjonalne, jak i czynniki społeczne oraz ekonomiczne (niemiecki cud gospodarczy lat 50. i początku 60.) - wzmocniły zaufanie społeczeństwa niemieckiego do demokratycznych partii politycznych, co miało pozytywny wpływ na trwałość i stabilność zachodnioniemieckiego systemu partyjnego. Po krótkiej fazie formowania (do 1953 roku) w obrębie zachodnioniemieckiego systemu partyjnego zaczęły dominować tendencje dośrodkowe. $\mathrm{W}$ tzw. fazie koncentracji trwającej do 1983 roku, a ściślej w latach 1961-1983, jedynie trzy partie - CDU/CSU, SPD i FDP - były reprezentowane w Bundestagu. Na przełomie lat 50. i 60. w wyniku modernizacji CDU/CSU i SPD wykształcił się specyficzny dla RFN model wielkich partii, tzw. model partii ogólnospołecznych (Volksparteien), zdefiniowany po raz pierwszy przez Otto Kirchheimera ${ }^{5}$. Volksparteien cechowały

3 U. Leuschner, Die Geschichte der FDP. Metamorphosen einer Partei zwischen rechts, sozialliberal und neokonservativ, Münster 2005, s. 4; A. Kruk, Wolna Partia Demokratyczna po zjednoczeniu Niemiec (1990-2013), Zielona Góra 2015, s. 19.

4 E. Holtmann, Der Parteienstaat in Deutschland. Erklärungen, Entwicklungen, Erscheinungsbilder, Bonn 2012, s. 12.

5 O. Kirchheimer, Der Wandel des westeuropäischen Parteiensystems, „Politische Vierteljahresschrift" 1965, nr 1(6), s. 20-41. 
się dużym potencjałem integracyjnym i szeroką ofertą programową kierowaną do różnych grup wyborców przy zachowaniu specyficznego profilu partii, silną bazą członkowską i znaczącym poparciem wyborców (nawet powyżej 40\%), silnym zapleczem i zdolnością do samodzielnego sprawowania władzy, dużym potencjałem koalicyjnym, ponadto posiadały silną podporę w swym tradycyjnym zapleczu (środowiskach katolickich w CDU/CSU i związkach zawodowych w wypadku SPD) ${ }^{6}$.

W praktyce obie wielkie partie ogólnospołeczne zdominowały zachodnioniemiecką scenę polityczną, a ich łączne poparcie w wyborach do Bundestagu w latach 1961-1987 nigdy nie spadło poniżej 80\%, przekraczając w szczytowym okresie fazy koncentracji 90\% (wybory z 1972 i 1976 roku). Jednakże w tym okresie żadna z obu Volksparteien nie była w stanie uzyskać większości w Bundestagu, co w perspektywie niechęci do zawierania koalicji z udziałem CDU/CSU i SPD (za wyjątkiem lat 1966-1969) powodowało, że rosło znaczenie dużo słabszej FDP, która stawała się niezbędnym partnerem do rządzenia dla jednej z wielkich partii. I to liberałowie mogli wybierać potencjalnego koalicjanta (w latach 1969-1982 byli w koalicji z SPD, po 1982 w koalicji z CDU/CSU) pełniąc rolę tzw. partii obrotowej. W ten sposób funkcjonował system dwuipółpartyjny.

Pojawienie się na początku lat 80. partii Zielonych i wejście ich do Bundestagu w 1983 roku zachwiało dotychczasowym układem partyjnym, który przekształcił się z systemu dwuipółpartyjnego w system złożony z dwóch dużych partii (CDU/CSU i SPD) i dwóch mniejszych, tzw. połówek (FDP, Zieloni). Stopniowemu ograniczeniu uległa $w$ tej sytuacji rola FDP, która straciła charakter partii obrotowej i zbliżyła się do chadecji, zaś partia Zielonych coraz bliżej współpracowała z SPD (pierwszą koalicję zawarto w Hesji w 1985 roku). Tym samym u schyłku lat 80. powoli zaczął kształtować się układ dwublokowy (rządzący blok mieszczański CDU/CSU-FDP i opozycyjny blok lewicowy SPD-Zieloni). Na początku lat 80 . XX wieku wraz z pojawieniem się partii Zielonych i później Republikanów zachodnioniemiecki

6 Na podstawie definicji zaproponowanej przez Petera Lösche: P. Lösche, Ende der Volksparteien, „Aus Politik und Zeitgeschichte” 2009, nr 51, s. 6-10. Szersze omówienie definicji Volksparteien i wyjaśnienie zasad tłumaczenia tego pojęcia na j. polski można znaleźć w moich wcześniejszych publikacjach: P. Kubiak, Przemiany wobrębie niemieckiego systemu partyjnego po 2009 roku, [w:] Polityka - kultura - społeczeństwo. Niemcy, Austria, Szwajcaria w pierwszej dekadzie XXI wieku, E. Kuczyński, M. Tomczyk (red.), Łódź 2013, s. 53-54; Tenże, System partyjny i partie polityczne zjednoczonych Niemiec (1990-2013), Poznań 2014, s. 40-42. 
system przeszedł w fazę transformacji, w trakcie której doszło do zjednoczenia obu państw niemieckich. Mimo zmian, jakie zaszły w latach 80., zachodnioniemiecki system partyjny cechował się stabilnością i trwałością, partie demokratyczne cieszyły się dużym zaufaniem społecznym, a całość legitymizowało znaczne poparcie społeczne wyrażone poprzez wysoką frekwencję w wyborach do Bundestagu (powyżej 85\% w latach 1953-1983).

Zupełnie odmienny charakter miał system partyjny Niemieckiej Republiki Demokratycznej. Tworzące go partie uformowały się jeszcze w trakcie okupacji radzieckiej. Choć formalnie system ten miał charakter wielopartyjny, to, podobnie jak w wypadku innych państw bloku socjalistycznego, miał on charakter systemu hegemonicznego, w którym dominującą rolę odgrywała Socjaldemokratyczna Partia Jedności (SED), pozostałe zaś partie i ugrupowania masowe pełniły drugorzędną rolę. Specjalna pozycja SED została zapisana w art. 1 ust. 1 konstytucji z 1968 roku$^{7}$. Upadek muru berlińskiego i kres reżimu komunistycznego w NRD doprowadziły do wykształcenia się na przełomie 1989 i 1990 roku specyficznego silnie zatomizowanego systemu partyjnego złożonego $\mathrm{z}$ dawnych partii reżimowych, niewielkich ugrupowań wywodzących się z demokratycznych ruchów obywatelskich, a także partii powstałych z inicjatywy siostrzanych partii zachodnioniemieckich. Ugrupowania te weszły w skład Izby Ludowej wyłonionej po raz pierwszy w wolnych wyborach 18 marca 1990 roku.

Analizując przemiany niemieckiego systemu partyjnego od momentu zjednoczenia w 1990 roku można wyróżnić cztery etapy jego rozwoju:

\footnotetext{
Konstytucja Niemieckiej Republiki Demokratycznej, Berlin 1968, s. 9.
}

8 W literaturze przedmiotu nie brak różnorodnych koncepcji podziału niemieckiego systemu partyjnego po 1990 r. W 2010 r. U. von Alemann wyodrębnił trzy fazy rozwoju niemieckiego systemu partyjnego po 1990 r.: fazę transformacji (1976-1994), fazę stabilizacji lat 1994-2002 i fazę płynną (od 2002 r.). U. von Alemann, Das Parteiensystem..., s. 50 i 77-96. Wolfgang Rudzio system partyjny RFN z lat 1983-2005 określił jako system dwóch grup partii z regionalnym systemem wschód (Zwei-Parteigruppensystem mit Regionalsystem Ost), a po 2005 r. jako bipolarny system pięciu partii w niedokończonej fazie formowania (Bipolares Fünfparteiensystem in unabgeschlossener Formierung). W. Rudzio, Das politische System der Bundesrepublik Deutschland, Wiesbaden 2011, s. 122-130. Oskar Niedermayer lata 1990-2005 określił jako fazę kształtowania się płynnego systemu pięciu partii, który po 2005 r. stał się systemem pięciopartyjnym, a po 2009 r. zakończyła się w nim dominacja obu wielkich Volksparteien. O. Niedermayer, Das Parteiensystem der Bundesrepublik Deutschland, [w:] Handbuch Parteienforschung, O. Niedermayer (red.), Wiesbaden 2013, s. 754-756. Zob. również: P. Kubiak, System partyjny..., s. 207-208. 
a) fazę integracji w 1990 roku (przeciągniętą w wypadku zjednoczenia Sojuszu 90 i partii Zielonych do 1993 roku);

b) okres kształtowania się płynnego systemu pięciopartyjnego w latach 1994-2005. Wówczas doszło do całkowitej zmiany koalicji rządzącej, kiedy po wyborach w 1998 roku rządzący od 1982 roku blok mieszczański CDU/CSU-FDP został zastąpiony przez blok lewicowy SPD-Zieloni;

c) system pięciu partii z lat 2005-2013, kiedy PDS (od 2007 roku Die Linke) zdołała utrwalić swą pozycję jako partia posiadająca znaczącą reprezentację w Bundestagu. W tym okresie doszło zarówno do wyraźnego osłabienia pozycji obu wielkich Volksparteien, jak i do odejścia od układu dwublokowego (wielka koalicja w latach 2005-2009);

d) wyłoniony po wyborach z 22 września 2013 roku nowy układ 4+2 (cztery partie reprezentowane w Bundestagu - CDU/CSU, SPD, Die Linke, Zieloni - oraz dwie partie, które znalazły się tuż poniżej progu wyborczego - FDP i AfD), który oznaczał odwrócenie dotychczasowego trendu i wzmocnienie pozycji obu Volksparteien, upadek FDP i pojawienie się nowego ugrupowania antysystemowego w postaci AfD. Układ $4+2$ był stabilny do czasu kryzysu migracyjnego (jesień 2015 roku).

ad a/ Kolejne etapy jednoczenia się państw niemieckich w 1990 roku zbiegły się $\mathrm{w}$ czasie z procesem transformacji zachodnioniemieckiego systemu partyjnego, pogłębiając go i wzbogacając o nowe akcenty, jakimi było pojawienie się młodych i na ogół niewielkich ugrupowań z Niemieckiej Republiki Demokratycznej. Perspektywa nieodległego zjednoczenia obu państw niemieckich skłoniła już na przełomie 1989 i 1990 roku największe partie zachodnioniemieckie do nawiązania kontaktów ze zbliżonymi ideowo ugrupowaniami działającymi w NRD i wspierania ich. Faza integracji zaczęła się jeszcze przed wyznaczoną na dzień 3 października 1990 roku oficjalną datą zjednoczenia obu państw niemieckich. Siostrzane ugrupowania z obu państw niemieckich zaczęły jednoczyć się już latem 1990 roku. Najwcześniej dokonała tego FDP, która 11 sierpnia w trakcie kongresu partii w Hanowerze połączyła się z wschodnioniemieckimi partiami: FDP, LDP, NDPD i Niemiecką Partią Forum. Podczas zjazdu SPD w Berlinie (26-27 września 1990 roku) doszło do zjednoczenia z wschodnioniemiecką SDP. Tymczasem CDU, która już w sierpniu 1990 roku wchłonęła wschodnioniemiecki Przełom Demokratyczny (DA), połączyła się z wschodnioniemiecką CDU i DBD na kongresie partii w Hanowerze (1-2 października 1990 roku). W praktyce mniejsze ugrupowania z NRD zostały wchłonięte przez ich odpowiedniki z Zachodu. Niemniej przyciągnięcie przez partie zachodnioniemieckie działaczy z byłej 
NRD, w większości ludzi młodych, ożywiło skostniałe już nieco tradycyjne partie zachodnioniemieckie. Wśród działaczy z NRD, którzy zasilili szeregi tradycyjnych partii zachodnioniemieckich znaleźli się m.in. Angela Merkel (wcześniej DA, później CDU) i przewodniczący Bundestagu w latach 1998-2005 Wolfgang Thierse (SPD) ${ }^{9} .3$ października 1990 roku skład Bundestagu został uzupełniony o 144 posłów z byłej NRD wybranych 18 marca 1990 roku do Izby Ludowej.

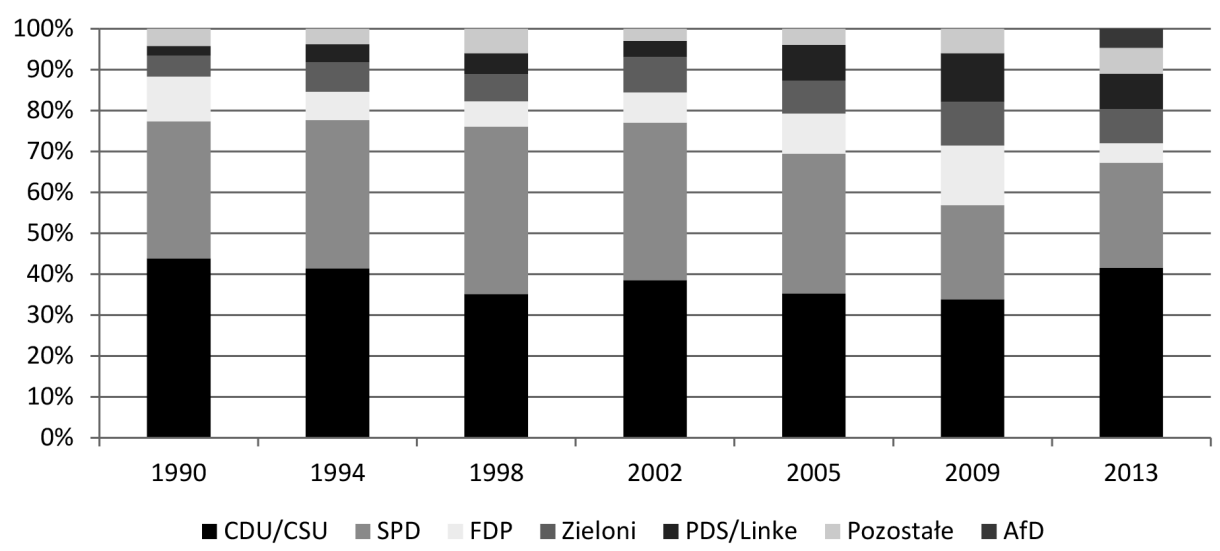

Wykres 1. Wyniki największych partii politycznych w wyborach do Bundestagu (1990-2013) Źródło: opracowanie własne na podstawie oficjalnych wyników wyborów do Bundestagu, https:// www.bundeswahlleiter.de/de/bundestagswahlen/downloads/bundestagswahlergebnisse/btw_ ab49_gesamt.pdf; P. Kubiak, System partyjny i partie polityczne zjednoczonych Niemiec (1990-2013), Poznań 2014, s. 211.

2 grudnia 1990 roku odbyły się pierwsze po zjednoczeniu wybory do Bundestagu XII kadencji. W drodze wyjątku obowiązywało w nich odrębne obliczanie klauzuli zaporowej dla obu części Niemiec, ze względu na fakt iż niewielkie ugrupowania wschodnioniemieckie nie miałyby szans w rywalizacji na szczeblu federalnym $\mathrm{z}$ silnymi i dobrze zorganizowanymi partiami zachodnioniemieckimi ${ }^{10}$. Wybory zakończyły się zwycięstwem CDU/CSU, które uzyskały 43,8\% głosów drugich i 319 mandatów, na SPD głosowało 33,5\% wyborców, co dało socjaldemokratom 239 miejsc w Bundestagu, a FDP poparło 11\% wyborców (79 mandatów). Do Bundestagu dostały się jeszcze dwa ugrupowania, które zdołały przekroczyć $5 \%$ poparcia na terenie Niemiec

$9 \quad$ P. Kubiak, System partyjny..., s. 209.

10 Szerzej o dyskusji i przyczynach wprowadzenia takiego rozwiązania: E. Jesse, Die Institutionellen Rahmenbedingungen der Bundestagswahl vom 2. Dezember 1990, [w:] Wahlen und Wähler. Analysen aus Anlaß der Bundestagswahl 1990, H. Klingemann, M. Kaase (red.), Berlin 1994, s. 32-34. 
wschodnich: PDS - 11,1\% poparcia w byłej NRD i 17 mandatów oraz wschodnioniemieccy Zieloni i Sojusz 90 - 6,2\% głosów i 7 mandatów. Tym sposobem $\mathrm{w}$ fazie integracji niemiecki system partyjny na poziomie federalnym przyjął kształt układu 3+2 (trzy duże partie posiadające frakcje w Bundestagu oraz dwie niewielkie wschodnioniemieckie grupy parlamentarne $)^{11}$. Wielkim przegranym wyborów byli zachodnioniemieccy Zieloni, którzy przed wyborami nie zdecydowali się połączyć ze swoimi siostrzanymi ugrupowaniami $z$ byłej NRD i nie przekroczyli bariery $5 \%$ na zachodzie Niemiec. Duży wpływ na wyniki wyborów miał znaczny entuzjazm będący następstwem zjednoczenia Niemiec, zwłaszcza na terenie wschodnich Niemiec. Beneficjentem takiej sytuacji były partie chadeckie i przede wszystkim liberałowie, którzy m.in. dzięki popularności Hansa-Dietricha Genschera zdobyli większe poparcie na obszarze byłej NRD ${ }^{12}$. Popularność FDP w Niemczech wschodnich okazała się jednak krótkotrwała, a rozczarowanie obywateli byłej NRD kosztami zjednoczenia było jedną z przyczyn narastającego $\mathrm{u}$ ich zniechęcenia do polityki i odwrócenia się od partii zachodnioniemieckich. Fazę integracji zakończyło zjednoczenie zachodnioniemieckich Zielonych z Sojuszem 90 dokonane w maju 1993 roku i powołanie przez ekologów do życia wspólnej partii Sojusz 90/Zieloni ${ }^{13}$.

ad b/ W latach 1994-2005 - fazie kształtowania się płynnego systemu pięciopartyjnego - niemiecki system partyjny na szczeblu federacji osiągnął pewien stopień stabilizacji. Liczba partii reprezentowanych w Bundestagu ustabilizowała się na poziomie pięciu: cztery tradycyjne partie zachodnioniemieckie tj. CDU/CSU, SPD, FDP i Sojusz 90/Zieloni oraz balansująca na granicy progu wyborczego postkomunistyczna PDS, silna przede wszystkim na obszarze

11 Można go również określić jako model 3+1+2 ze względu na fakt ukonstytuowania się w Bundestagu dwóch dużych frakcji (CDU/CSU oraz SPD), jednej średniej (FDP) oraz dwóch małych grup parlamentarnych (PDS, Zieloni). W latach 1991-1994 z punktu widzenia relewancji partii politycznych (a więc realnego wpływu partii na sytuację polityczną) na szczeblu federalnym możemy mówić o systemie trzech partii politycznych.

12 FDP na terenie byłej NRD uzyskała aż 12,6\% poparcia. Liberałom udało się nawet po raz pierwszy od wyborów w 1957 r. zwyciężyć w okręgu jednomandatowym (w Halle, skąd pochodził H.-D. Genscher). J. Dittberner, Die FDP. Geschichte, Personen, Organisation, Perspektiven. Eine Einführung, Wiesbaden 2005, s. 80.

13 Szerzej o kulisach procesu zjednoczeniowego: L. Probst, Bündnis 90/Die Grünen, [w:] Handbuch der deutsche Parteien, F. Decker, V. Neu (red.), Wiesbaden 2007, s. $175-176$. 
Niemiec wschodnich. Co istotne, doszło w tym okresie do całkowitej zmiany koalicji rządzącej. Wybory do Bundestagu w 1994 roku (jak i cała seria wyborów do parlamentów krajowych i Parlamentu Europejskiego) przyniosły osłabienie partii rządzącej koalicji CDU/CSU-FDP i wzrost poparcia dla lewicowej opozycji. Zwyciężyły wprawdzie partie chadeckie (41,4\% głosów), lecz w porównaniu do wyborów z 1990 roku uzyskały wynik gorszy o 2,4 p.p. Jeszcze większe straty poniosła koalicyjna FDP, na którą głosowało 6,9\% wyborców (-4,1 p.p.). Opozycyjna SPD uzyskała $36,6 \%$ poparcia (+2,9 p.p.), a Sojusz 90/Zieloni w rok po zjednoczeniu uzyskał 7,3\% głosów. Na mocy tzw. klauzuli mandatowej (tj. dzięki zwycięstwu w co najmniej trzech okręgach jednomandatowych) do Bundestagu dostało się 30 posłów PDS, mimo że partia uzyskała w wyborach 4,4\% głosów i nie przekroczyła granicy klauzuli zaporowej. Po wyborach na kolejną kadencję u władzy pozostała koalicja CDU/CSU-FDP, lecz pozycja rządu w Bundestagu XIII kadencji była o wiele słabsza niż w latach 1991-1994. Wybory do parlamentów krajowych z lat 1995-1998 przyniosły serię niepowodzeń chadecji i liberałów, co skutkowało utratą przez rząd H. Kohla poparcia większości Rady Federalnej i w praktyce umożliwiało opozycji blokowanie inicjatyw rządowych w Bundesracie. Była to również zapowiedź zmian, jakie miały przynieść kolejne wybory do Bundestagu. Wybory z 27 września 1998 roku były swego rodzaju plebiscytem za lub przeciw kanclerzowi H. Kohlowi, choć opozycyjna SPD i jej kandydat Gerhard Schröder zdołali dzięki skutecznej kampanii wyborczej przekonać do siebie większość wyborców o orientacji centrowej (w tym część dawnego elektoratu CDU). Wybory zakończyły się wyraźnym zwycięstwem SPD, która uzyskała 40,9\% głosów drugich, (+4,5 p.p. w stosunku do wyborów z 1994 roku) a partie chadeckie poparte przez 35,1\% wyborców poniosły dotkliwe straty (-6,3 p.p.). Sojusz 90/Zieloni (6,7\% poparcia) i FDP $(6,2 \%)$ odnotowały niewielkie straty, a postkomunistycznej PDS udało się po raz pierwszy przekroczyć granicę progu wyborczego uzyskując w skali całych Niemiec (5,1\% głosów drugich). W następstwie wyborów do władzy doszła nowa koalicja SPD-Zieloni. Po raz pierwszy w dziejach RFN doszło do całkowitej zmiany koalicji rządzącej (wcześniej przynajmniej jeden z koalicjantów pozostawał w kolejnym gabinecie). Można zatem przyjąć, że w 1998 roku ukazana została w pełnej krasie istota kształtującego się po 1983 roku układu dwublokowego: jeden blok, tzw. mieszczański (CDU/CSU-FDP) został zastąpiony przez drugi blok, tj. blok partii lewicowych (SPD-Zieloni). Zakończył się zatem 16-letni okres rządów koalicji CDU/CSU-FDP oraz 29-letni nieprzerwany udział FDP w koalicji rządzącej. Wybory z 27 września 1998 roku zakończyły trwający nieprzerwanie od wyborów z 1976 roku okres przewagi 
chadecji nad SPD, tzw. asymetrii strukturalnej na korzyść partii chadeckich. Kolejne wybory do Bundestagu, przeprowadzone 22 października 2002 roku, wieńczyły jedną z najbardziej zaciętych kampanii wyborczych. Wyborcy nie wskazali zdecydowanego zwycięzcy, gdyż SPD i CDU/CSU zyskały niemal identyczne poparcie (po 38,5\%), lecz dzięki większemu poparciu, jakie zyskał Sojusz 90/Zieloni (8,6\%) aniżeli FDP (7,4\%), dotychczasowa koalicja SPD-Zieloni zachowała niewielką większość w Bundestagu XIV kadencji. PDS zdołała wprowadzić do Bundestagu jedynie dwóch posłów z okręgów jednomandatowych, gdyż uzyskała zaledwie $4,0 \%$ poparcia i nie zdołała zwyciężyć w co najmniej trzech okręgach jednomandatowych (klauzula mandatowa). W latach 2003-2005 w Niemczech toczyła się zażarta debata wokół rządowego programu reform Agenda 2010 (w szczególności wokół pakietu Hartz IV). Program reform spotkał się z ostrymi protestami lewego skrzydła SPD i związków zawodowych, a sama SPD poniosła znaczące straty w 11 kolejnych wyborach do parlamentów krajowych z lat 2003-2005. Tymczasem na poziomie krajów federacji po 2001 roku coraz większe sukcesy odnosiły partie skrajnie prawicowe i populistyczne jak NPD w Saksonii w 2004 roku, czy też partia Schilla w Hamburgu w 2001 roku, co świadczyło o narastaniu tendencji odśrodkowych w niemieckim systemie partyjnym.

ad c/ W roku 2005 doszło do znaczących przemian w obrębie niemieckiego systemu partyjnego w następstwie przedterminowych wyborów do Bundestagu przeprowadzonych 18 września. Podobnie jak w 2002 roku wybory nie przyniosły zdecydowanego zwycięzcy. Największe poparcie uzyskały partie chadeckie, na które głosowało 35,2\% wyborców (-3,3 p.p. w porównaniu do wyborów z 2002 roku), a tuż za nimi znalazła się SPD z poparciem 34,2\% głosujących (-4,3 p.p.). Wzrosło znaczenie partii średnich, przede wszystkim FDP (9,8\% głosów, +2,4 p.p.) i lewicowego sojuszu Linkspartei.PDS ${ }^{14}$ (8,7\%, $+4,7$ p.p. w porównaniu do wyniku PDS z 2002 roku), a poparcie dla Sojuszu 90/Zielonych pozostało na zbliżonym poziomie ( $8,1 \%$ głosów, $-0,3$ p.p.). Tak duży sukces Linkspartei.PDS utwierdził balansującą dotychczas na granicy

14 Latem 2005 r. PDS udało się zawrzeć sojusz wyborczy z zachodnioniemiecką WASG skupiającą lewicowych przeciwników programu Agenda 2010 (a zwłaszcza pakietu Hartz IV), co dawało nadzieję na przekroczenie granicy progu wyborczego. $\mathrm{Na}$ mocy porozumienia przedstawiciele WASG wystartowali na wspólnej liście wyborczej Linkspartei.PDS. Dzięki temu PDS udało się uzyskać znaczniejsze wpływy na zachodzie Niemiec, co zaowocowało późniejszym sukcesem w wyborach. A. Malycha, P. Winters, Geschichte der SED. Von der Gründung bis zur Linkspartei, Bonn 2009, s. 402-403. 
progu wyborczego PDS w roli liczącej się partii politycznej na niemieckiej scenie politycznej, a system partyjny przekształcił się w po wyborach w system pięciu partii. W obliczu trudności z powołaniem koalicji opartej na dotychczasowych blokach (mieszczańskim CDU/CSU-FDP i lewicowym SPD-Zieloni), które nie miały większości w Bundestagu XVI kadencji, zdecydowano się utworzyć rząd wielkiej koalicji CDU/CSU-SPD kanclerz Angeli Merkel. Utworzenie koalicji złożonej z obu Volksparteien zapewniło rządowi poparcie znaczącej większości Bundestagu, jednak w partiach koalicyjnych uwidoczniło się znaczące niezadowolenie wynikające z faktu wspólnej koalicji z głównym konkurentem. Tymczasem na lewej stronie niemieckiej sceny politycznej doszło do znaczących przetasowań. W czerwcu 2007 roku zakończył się proces zjednoczeniowy dawnej PDS z zachodnioniemieckim WASG w wyniku czego powołano do życia nową partię - Die Linke ${ }^{15}$. W latach 2006-2009 SPD była targana wewnętrznymi sporami, a jej notowania sondażowe spadły latem 2008 roku do poziomu $25 \%{ }^{16}$. Światowy kryzys na rynkach finansowych i zbliżający się termin wyborów do Bundestagu spowodowały, że w pierwszej połowie 2009 roku współpraca partii koalicyjnych była bardzo utrudniona. Wyniki przeprowadzonych 27 września 2009 roku wyborów do Bundestagu XVII kadencji przyniosły klęskę SPD i wzrost znaczenia partii średnich. Wybory zakończyły się zwycięstwem CDU/CSU, na które głosowało 33,8\% wyborców (-1,4 p.p. w porównaniu do wyborów z 2009 roku). Pomimo niewielkiej utraty poparcia partie chadeckie uzyskały więcej mandatów dzięki zdobyciu aż 24 mandatów nadwyżkowych. Dotkliwe straty poniosła SPD, na którą głosowało zaledwie $23 \%$ wyborców $(-11,2$ p.p.) i był to najgorszy wynik SPD w wyborach do Bundestagu od początku istnienia Republiki Federalnej Niemiec. Wielki sukces w wyborach odniosły partie średnie pozostające w latach 2005-2009 w opozycji wobec rządu wielkiej koalicji. Na FDP głosowało 14,6\% wyborców (+4,8 p.p.), na Die Linke $11,9 \%$ (+3,2 p.p.), a na Sojusz 90/Zielonych $10,7 \%$ (+2,6 p.p.). Rozstrzygnięcie wyborcze z 2009 roku miało istotne znaczenie z perspektywy ewolucji niemieckiego systemu partyjnego z kilku powodów. Zdaniem Oskara Niedermayera zakończyło ono trwającą od lat 50. dominację dwóch wielkich Volksparteien w (zachodnio-)niemieckim systemie partyjnym, gdyż zdobyły one zaledwie $56,8 \%$ poparcia i obsadziły w Bundestagu mniej niż $2 / 3$ miejsc

15 Tamże, s. 403.

16 Forschungsgruppe Wahlen, sondaż Politbarometer, sierpień 2008, http://www.forschungsgruppe.de/Umfragen/Politbarometer/Archiv/Politbarometer_2008/August_2008/(dostęp: 18.06.2016). 
(posłowie CDU/CSU obsadzili 38,4\% wszystkich mandatów, a posłowie SPD $23,5 \%)^{17}$. Zdaniem Ulricha Eitha tak dobry wynik Die Linke także na zachodzie Niemiec $(8,3 \%)$ pozwolił partii osiągnąć status partii ogólnoniemieckiej, a wybory z 2009 roku utrwaliły istnienie w Niemczech systemu złożonego z pięciu partii, co oznaczało "przejście” do nowego etapu rozwoju systemu partyjnego, podobnie jak to miało miejsce w wypadku wyborów z 1983 roku i partii Zielonych ${ }^{18}$. W następstwie wyborów do władzy po 11 latach przerwy powrócił blok mieszczański (koalicja CDU/CSU-FDP), a opozycja w Bundestagu rekrutowała się w latach 2009-2013 z partii lewicowych: SPD, Die Linke i Sojusz 90/Zieloni.

ad d/ W latach 2010-2013 doszło do znacznych przeobrażeń na niemieckiej scenie politycznej, które miały wpływ na wyniki wyborów do Bundestagu z 22 września 2013 roku. Przede wszystkim chodzi o kryzys FDP zapoczątkowany u progu 2010 roku, kiedy liberałowie zgodzili się ustąpić koalicjantom z CDU/CSU w tak ważnej sprawie jak perspektywa obniżki podatków. Skutkiem tego w 2010 roku gwałtownie spadły sondażowe notowania FDP, a po serii niepowodzeń w wyborach krajowych doszło wiosną 2011 roku do zmian w kierownictwie partii. Kryzys w FDP okazał się na tyle głęboki, że do końca kadencji partia nie zdołała się z nim uporać ${ }^{19}$. Toczące się debaty wokół fundamentalnych dla poszczególnych partii kwestii przynosiły im czasowy wzrost poparcia $\mathrm{w}$ sondażach i sukcesy w wyborach do parlamentów krajowych - tak było wiosną 2011 roku, kiedy głównym tematem dyskursu politycznego była istotna dla partii Zielonych kwestia przyszłości energetyki atomowej, a także dyskusja wokół swobody w internecie i protesty przeciwko umowie ACTA na przełomie lat 2011/2012, niezwykle ważne z perspektywy Partii Piratów. W lutym 2013 roku powołano do życia Alternatywę dla Niemiec (Alternative für Deutschland, AfD), nowe ugrupowanie polityczne przeciwne polityce wspierania zadłużonych państw strefy euro z południa Europy, postulujące $\mathrm{w}$ dalszej perspektywie powrót do niemieckiej marki. Wybory do

17 O. Niedermayer, $d z$. cyt., s. 755-756. Zdaniem autora, aby zachowana została dominacja obu wielkich partii, musiałyby one mieć $2 / 3$ miejsc w Bundestagu, a słabsza z nich posiadać co najmniej 25\% mandatów i mieć dwukrotnie więcej mandatów od kolejnej partii. Żaden z tych warunków nie został spełniony w Bundestagu XVII kadencji.

18 U. Eith, Volksparteien unter Druck. Koalitionspositionen, Integrationsfähigkeit und Kommunikationsstrategien nach der Übergangswahl 2009, [w:] Die Bundestagswahl 2009. Analysen der Wahl-, Parteien-, Kommunikations- und Regierungsforschung, (red.) K.-R. Korte, Wiesbaden 2010, s. 117.

19 Szerzej: A. Kruk, dz. cyt., s. 100-101. 
Bundestagu XVIII kadencji przeprowadzono według znowelizowanej ordynacji wyborczej minimalizującej korzyści z mandatów nadwyżkowych i głosowania na koalicje (tzw. dzielenie głosów). Zwycięstwo w wyborach odniosły partie chadeckie, na które głosowało 41,5\% wyborców (wzrost o 7,7 p.p.), SPD uzyskała $25,7 \%$ poparcia (+2,7 p.p.). Znaczne straty odniosły partie średnie: na Die Linke głosowało 8,6\% wyborców (-3,3 p.p.), a na Sojusz 90/Zielonych $8,4 \%$ (-2,3 p.p.). Granicy 5\% nie zdołała przekroczyć FDP, która uzyskała 4,8\% poparcia $(-9,8$ p.p.) oraz debiutująca w wyborach AfD, na którą głos oddało $4,7 \%$ wyborców. W wyniku wyborów ukształtował się na poziomie federacji format 4+2 (cztery partie reprezentowane w Bundestagu + AfD i FDP, które znalazły się tuż poniżej progu wyborczego $)^{20}$. Istotnym następstwem wyborów z 22 września 2013 roku była klęska FDP, która znalazła się po raz pierwszy w dziejach Republiki Federalnej Niemiec poza ławami Bundestagu. Inną ważną konsekwencją wyborów do Bundestagu XVIII kadencji było odzyskanie przez obie Volksparteien (zwłaszcza CDU/CSU) części utraconych w wyborach 2005 i 2009 roku wpływów, dzięki czemu odzyskały one dominującą pozycję w Bundestagu (ponad 80\% mandatów). Jednak tak silna pozycja CDU/CSU i SPD w Bundestagu wynika po części z ich nadreprezentacji w parlamencie, gdyż na partie, które nie weszły do Bundestagu padło aż 15,8\% głosów, a większość przesłanek wskazywała na to, iż nie ma podstaw by sądzić, że nastąpiła trwała zmiana trendu na korzyść wielkich partiii ${ }^{21}$. Podobnie jak w 2005 roku po długich negocjacjach powołano rząd wielkiej koalicji CDU/CSU-SPD kanclerz Angeli Merkel. Aż do jesieni 2015 roku notowania sondażowe niemieckich partii politycznych podlegały jedynie minimalnym zmianom i układ sił wyłoniony po wyborach wydawał się mieć charakter trwały.

Jednym z ważniejszych następstw zjednoczenia Niemiec było pojawienie się znaczących różnic w preferencjach wyborczych pomiędzy mieszkańcami Niemiec wschodnich i zachodnich, co w efekcie doprowadziło do wykształcenia się specyficznego podsystemu partyjnego na obszarze byłej NRD. Jeszcze w trakcie pierwszych wyborów do parlamentów krajowych w nowych krajach federacji jesienią 1990 roku i podczas pierwszych wspólnych wyborów do Bundestagu różnice te nie były aż tak znaczące. Niemniej - jak zauważyła

20 P. Kubiak, Wybory do Bundestagu z 22 września 2013 roku - analiza i konsekwencje, „Przegląd Zachodni” 2014, nr 1, s. 40.

21 E. Jesse, Nach allen Seiten offen? Der Ausgang der Bundestagswahl 2013 und mögliche Folgen für das Parteiensystem und das Koalitionsgefüge, „Zeitschrift für Politik” 2013, nr 4, s. 382. 
Ewa Bojenko-Izdebska - działacze wschodnioniemieckich partii i ruchów obywatelskich już na początku transformacji zostali pozbawieni możliwości współtworzenia i identyfikacji z partiami politycznymi, a w zamian musieli zaakceptować liderów i programy powstałe $\mathrm{w}$ warunkach zachodnioniemieckiej demokracji ${ }^{22}$. Chwilowy entuzjazm wynikający ze zjednoczenia minął, gdy bardzo szybko okazało się, że koszty transformacji są ogromne, a na efekty trzeba będzie długo czekać. Niemcy ze Wschodu znaleźli się w o wiele gorszej sytuacji ekonomicznej niż ich rodacy mieszkający na Zachodzie. Na Wschodzie szybko rosło bezrobocie, upadały liczne przedsiębiorstwa niedostosowane do gospodarki rynkowej, a stopa życiowa mieszkańców Niemiec wschodnich była na znacznie niższym poziomie.

Wszystko to powodowało, że na początku lat 90 . nasiliło się zjawisko tęsknoty za czasami NRD (ostalgii). Rozczarowanie Niemców wschodnich przebiegiem transformacji i słabe przywiązanie do partii tworzonych na wzór zachodnioniemieckich doprowadziły w latach 1991-1994 do masowego występowania z partii (np. z FDP) mieszkańców byłej NRD i generalnego rozczarowania do polityki i demokracji w ogóle. Zyskiwała na tym PDS, która jawiła się jako partia reprezentująca interesy Niemców ze wschodu. Począwszy od wyborów krajowych z roku 1994 roku, na obszarze byłej NRD wykształcił się na okres ok. 10 lat układ „3+” złożony z trzech dużych partii (CDU, SPD i właśnie PDS) + ewentualnie dodatkowej partii, która zdołała przekroczyć granicę progu wyborczego ${ }^{23}$.

Po 2002 roku następowała stopniowa pluralizacja systemów partyjnych krajów federacji z Niemiec wschodnich, gdzie granicę progu wyborczego przekraczało na ogół od 4 do 6 ugrupowań, w tym partie skrajnie prawicowe jak np. NPD w Saksonii w 2004 roku. Zachowanie wyborcze mieszkańców Niemiec wschodnich jest o wiele trudniejsze do przewidzenia, przywiązanie do partii jest o wiele słabsze niż na zachodzie, a udział głosujących na partie skrajne, bądź antysystemowe znacznie wyższy, np. w wyborach $\mathrm{z}$ lat 2013-2016 odnotowano znaczne większe poparcie dla AfD w Niemczech wschodnich. Jeszcze w latach 90. głosy wyborców z byłej NRD nie miały większego wpływu na kształt koalicji na szczeblu federalnym. Zmieniło się to w kolejnych wyborach, np. w roku 2002, kiedy SPD udało się zdystansować na finiszu kampanii wyborczej chadecję, głównie dzięki głosom mieszkańców Niemiec wschodnich. Efektem mniejszego zaangażowania politycznego

22 E. Bojenko-Izdebska, „Wschód głosuje inaczej”. Preferencje wyborcze w nowych krajach federacji po 1990 roku, „Przegląd Zachodni” 2014, nr 1, s. 46.

23 Tamże, s. 48. 
Niemców ze Wschodu jest niższa niż na Zachodzie frekwencja wyborcza notowana w wyborach do Bundestagu (wykres 2) i parlamentów krajowych.

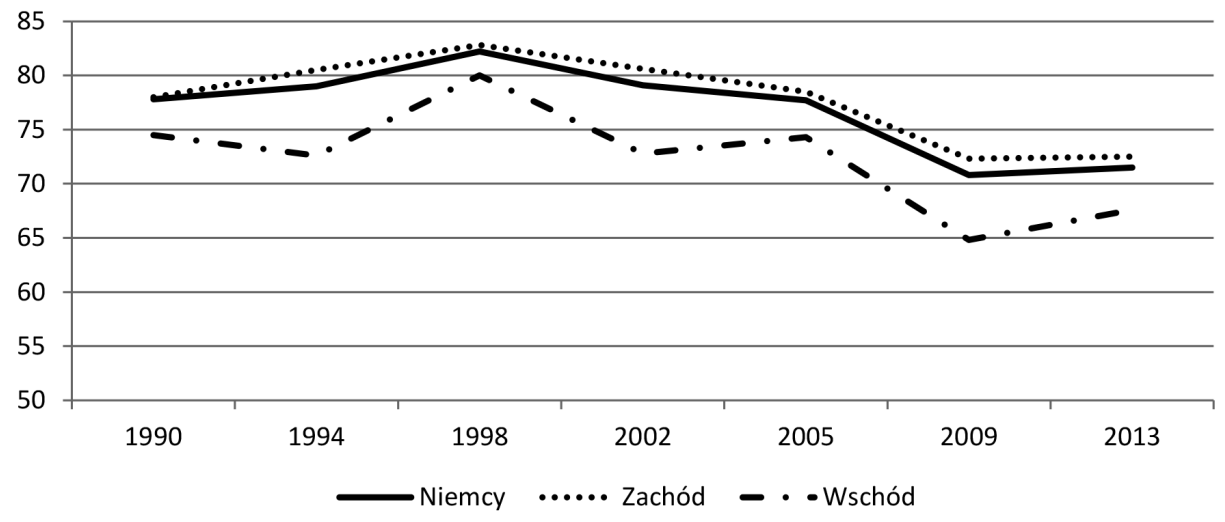

Wykres 2. Frekwencja w wyborach do Bundestagu 1990-2013.

Źródło: opracowanie własne na podstawie wyników wyborów do Bundestagu. Zob. również: P. Kubiak, System partyjny i partie polityczne zjednoczonych Niemiec (1990-2013), Poznań 2014, s. 238.

Po 1990 roku nastąpiło stopniowe osłabienie znaczenia wielkich partii ogólnospołecznych, które zdominowały zachodnioniemiecki system partyjny w latach 1960-1989. Już pojawienie się partii Zielonych w Bundestagu w 1983 roku rozpoczęło powolny proces utraty poparcia przez obie Volksparteien, pogłębiony po zjednoczeniu Niemiec. Na obszarze Niemiec wschodnich pozycja SPD i CDU była znacznie słabsza niż na Zachodzie. Wynikało to ze słabszego przywiązania tutejszych mieszkańców do tradycyjnych partii zachodnioniemieckich, jak również silnej konkurencji ze strony PDS (później Die Linke) roszczącej sobie prawo do bycia jedynym reprezentantem interesów mieszkańców Niemiec wschodnich. Zestawienie wyników głosowania w wyborach do Bundestagu z lat 1990-2013 w obu częściach Niemiec pokazuje, że każdorazowo obie Volksparteien uzyskiwały łącznie znacznie niższe poparcie na wschodzie niż na zachodzie Niemiec ${ }^{24}$. Tymczasem w skali całych Niemiec sumaryczne poparcie dla Volksparteien spadło poniżej $80 \%$, lecz do czasu wyborów z 2002 roku utrzymywało się na poziomie 76-77,8\% (zob. wykres 3).

24 Na wschodzie Niemiec CDU i SPD uzyskiwały każdorazowo niższe wyniki niż na zachodzie: w 1990 r. na CDU i SPD głosowało tutaj 66,1\% wyborców (80,0\% na zachodzie), w 1994 r. - 70,0\% (79,6\% na zachodzie), w 1998 r. - 62,4\% (79,3\% na zachodzie), w 2002 r. - 68,0\% (79,1\% na zachodzie), w 2005 r. - 55,7\% (72,5\% na zachodzie), w 2009 r. - 47,7\% (58,7\% na zachodzie), a w 2013 r. - 56,4\% (69,6\% na zachodzie). P. Kubiak, System partyjny..., s. 241. 


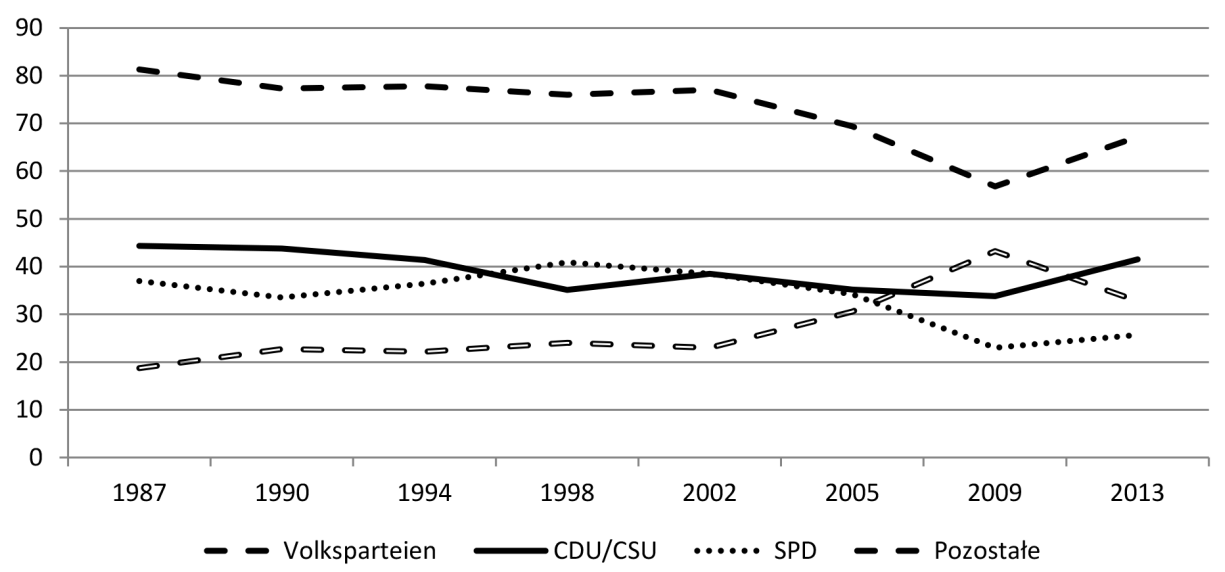

Wykres 3. Poparcie dla Volksparteien (CDU/CSU i SPD) w wyborach do Bundestagu w latach 1987-2013. Źródło: opracowanie własne na podstawie wyników wyborów.

Spadek sumarycznego poparcia dla CDU/CSU i SPD zaznaczył się po wyborach z 2005 roku, kiedy na obie partie głosowało łącznie 69,4\%, a w kolejnych wyborach (z 2009 roku) obie partie uzyskały zaledwie 56,8\% głosów drugich i był to ich najniższy sumaryczny wynik od początku istnienia RFN. Tak niski wynik obu partii stał się podstawą do wysuwania przez badaczy licznych hipotez mówiących o końcu Volksparteien w ich dotychczasowej formie, bądź też wieszczących koniec ich dominującego wpływu na niemiecki system partyjny. Sukces wyborczy chadecji odniesiony w kolejnych wyborach z 2013 roku i ustabilizowanie się poparcia dla CDU/CSU i SPD w sondażach z lat 2014 i 2015 nieco tę dyskusję przytłumiły.

Kryzys Volksparteien zasadzał się na następujących przesłankach: utracie poparcia wyborców, a co za tym idzie wpływów politycznych; erozji ich dotychczasowego tradycyjnego elektoratu i osłabieniu trwałych więzi między partią a tym środowiskiem (np. między SPD a związkami zawodowymi); osłabieniu zdolności integracyjnych partii ogólnospołecznych; spadku liczby członków obu partii, głównie w następstwie wymierania najstarszych członków, który nie jest rekompensowany napływem młodych kadr - starzenie się ich bazy członkowskiej; narastającej konkurencji ze strony innych partii (w wypadku SPD ze strony Die Linke i Sojuszu 90/Zielonych, w wypadku CDU/CSU przede wszystkim ze strony AfD po 2013 roku ${ }^{25}$. Kryzys dotyka jednak przede wszystkim SPD, która w latach 2003-2009 pogrążona była w problemach wewnętrznych. Również udział w koalicji z partiami chadeckimi w roli słabszego partnera (2005-2009 i od 2013 roku) odbił się w dłuższej perspektywie negatywnie na notowaniach SPD. Po wyborach z 2009 roku SPD stała się partią

25 P. Lösche, $d z$. cyt., s. 7-9. 
nie będącą w stanie przekroczyć wyraźnie progu 25\% poparcia na szczeblu federalnym, co według niektórych klasyfikacji oznacza iż nie mieści się w wyznaczonych dla Volksparteien granicach (minimum 30 lub 35\% poparcia).

Cechą charakterystyczną zachodnioniemieckiego systemu partyjnego była wysoka liczebność członków najważniejszych partii politycznych. W wyniku zjednoczenia uległa ona jeszcze powiększeniu o nowych członków z byłej NRD. Jednak w pierwszej połowie lat 90 . wszystkie większe partie niemieckie odczuły znaczny odpływ członków, głównie rozczarowanych transformacją mieszkańców Niemiec wschodnich. W drugiej połowie lat 90. trend spadkowy osłabł i zaczął się stabilizować. O ile w wypadku partii średnich (FDP, PDS, Zieloni) został on zahamowany, to nadal utrzymywał się w odniesieniu do SPD i CDU, głównie przez wymieranie najstarszych członków (zob. wykres 4) ${ }^{26}$. Zjawisko kurczącej się bazy członkowskiej niemieckich partii politycznych nie jest niczym wyjątkowym w dojrzałych demokracjach zachodnioeuropejskich, jednak rozmiar spadku liczby członków (np. w odniesieniu do SPD) jest już zjawiskiem niepokojącym.

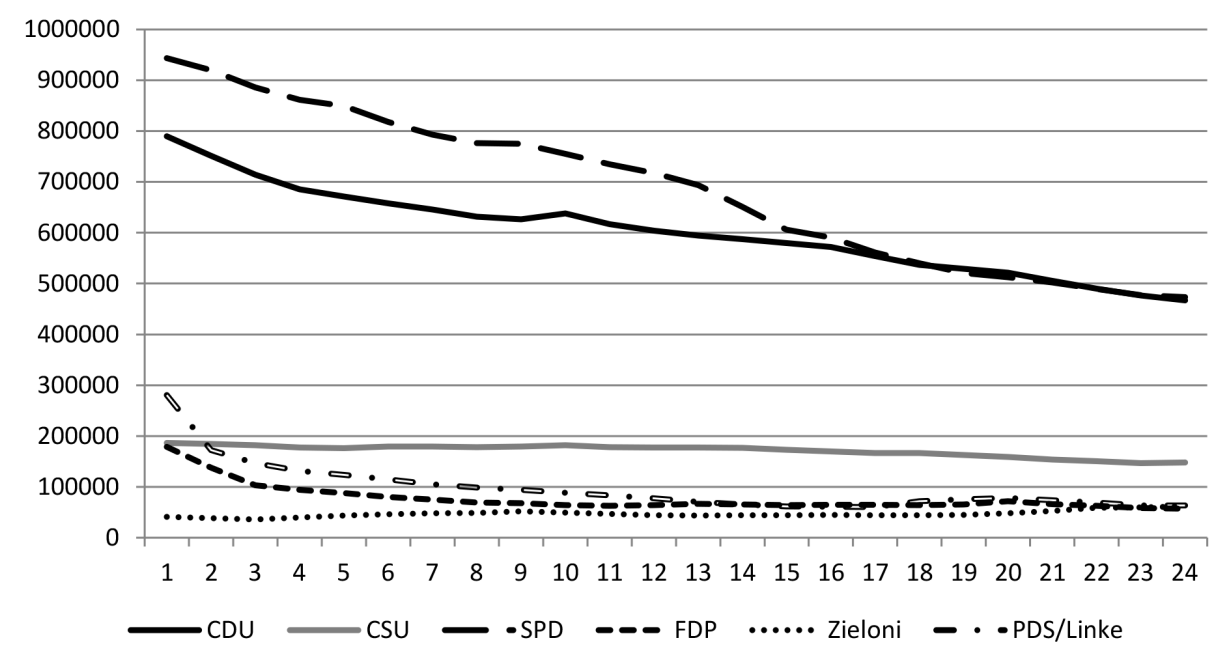

Wykres 4. Liczba członków największych niemieckich partii politycznych w latach 1990-2014.* Źródło: O. Niedermayer, Parteimitgliederschaften im Jahre 2014, „Zeitschrift für Parlamentsfragen” 2014, nr 2, s. 376.

* Liczby 1-24 w opisie osi X oznaczają stan na koniec kolejnych lat: np. 1 stan na dzień 31.12.1991 roku, 24 stan na dzień 31.12.2014 roku.

26 Wynikał on m.in. z faktu, że SPD i partie chadeckie w latach 60. i 70. XX w. odnotowały znaczny napływ nowych członków (głównie w wieku ok. 40 lat), którzy po 2000 r. zaczęli powoli wymierać. Szerzej o masowym napływie członków do SPD w latach 60. i jego przyczynach: P. Lösche, F. Walter, Die SPD. Klassenpartei-Volkspartei-Quotenpartei, Darmstadt 1992, s. 137-148. 
W ciągu dwóch kolejnych lat po wyborach do Bundestagu XVIII kadencji przeprowadzonych w 2013 roku na niemieckiej scenie politycznej nastąpiła stabilizacja. Od wyborów do października 2015 roku notowania sondażowe partii politycznych ulegały jedynie minimalnym zmianom i we wrześniu 2015 roku były zbliżone do ostatnich wyników wyborów do Bundestagu ${ }^{27}$. Oskar Niedermayer - czołowy niemiecki politolog - dokonując na początku października 2015 roku bilansu pierwszych dwóch lat działalności Bundestagu XVIII kadencji, stwierdził, że przemiany zachodzące w tym okresie (wrzesień 2013-wrzesień 2015) potwierdziły powrót do tradycyjnego modelu dominacji dwóch wielkich partii na niemieckiej scenie politycznej. Wiele przesłanek (m.in. utrzymujące się do września 2015 roku poparcie sondażowe zbliżone do wyników ostatnich wyborów do Bundestagu, jak również niesłabnące zaufanie do kanclerz Angeli Merkel) wydawało się potwierdzać powyższą tezę. Niemniej sam autor zaznaczył już wówczas, że narastające $\mathrm{w}$ społeczeństwie obawy związane z kryzysem migracyjnym mogą doprowadzić do niespodziewanych zmian na niemieckiej scenie politycznej ${ }^{28}$. W rzeczywistości kryzys migracyjny doprowadził do znaczących przetasowań wśród niemieckich partii, stając się równocześnie głównym tematem debaty publicznej w RFN. Wiosną 2016 roku poparcie dla największych niemieckich partii politycznych znacząco różniło się od sytuacji z września 2015 roku, kiedy kryzys migracyjny stawał się coraz większym wyzwaniem dla Niemiec (zob. wykres 5).

W następstwie kryzysu osłabieniu uległa pozycja partii wielkiej koalicji, w szczególności CDU. To właśnie przez partię kanclerz A. Merkel przebiega główna linia podziału na zwolenników i przeciwników polityki „otwartych drzwi” wobec imigrantów. Również SPD odnotowała znaczny spadek notowań sondażowych wynikających m.in. z niechęci części zwolenników SPD do udziału ich partii w koalicji z partiami chadeckimi oraz słabości przywództwa Sigmara Gabriela. Ogromny wzrost poparcia odnotowała za to AfD, partia konsekwentnie opowiadająca się za ograniczeniem napływu

27 Na przykład według pierwszego wrześniowego sondażu Politbarometer przeprowadzonego na zlecenie telewizji ZDF na CDU/CSU chciało głosować 42\% respondentów (partia uzyskała 41,5\% w wyborach do Bundestagu z 2013 r.), na SPD 26\% (25,7\% w 2013 r.), na Die Linke 8\% (8,6\% w 2013 r.), na Sojusz 90/Zielonych 10\% (8,4\% w 2013 r.), na FDP 4\% (4,8\% w 2013 r.), na AfD 4\% (4,7\% w 2013 r.), http:// www.forschungsgruppe.de/Umfragen/Politbarometer/Archiv/Politbarometer_2015/ September_I_2015/(dostęp: 19.06.2016).

28 O. Niedermayer, Halbzeit. Die Entwicklung des Parteiensystems nach der Bundestagswahl 2013, „Zeitschrift für Parlamentsfragen” 2015, nr 4, s. 832-842, 850. 
imigrantów do Niemiec. Kryzys migracyjny pozwolił AfD na nowo się zintegrować w opozycji do oficjalnej polityki rządu, co przyniosło partii spory sukces w marcowych wyborach do trzech parlamentów krajowych (Badenia-Wirtembergia, Nadrenia-Palatynat, Saksonia-Anhalt). Dynamika zmian jaka dotknęła niemiecką scenę polityczną pod wpływem kryzysu migracyjnego utrudnia stawianie prognoz wyborczych przed kolejnymi wyborami do Bundestagu (jesień 2017 roku).

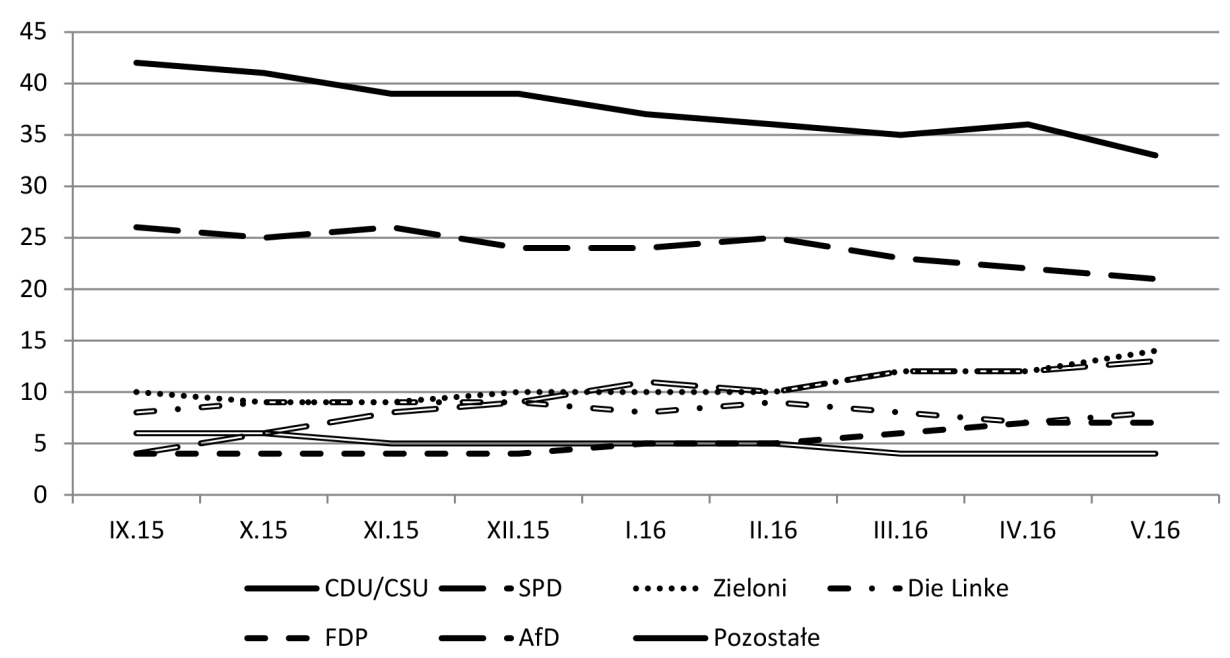

Wykres 5. Sondażowe poparcie dla niemieckich partii politycznych (Politbarometer) w okresie wrzesień 2015-maj 2016.

Źródło: Sondaże Politbarometer opracowane przez Forschungsgruppe Wahlen dla telewizji ZDF, http://www.forschungsgruppe.de/.

$$
* * *
$$

Zjednoczenie Niemiec miało również istotny wpływ na niemiecki system partyjny. W wyniku zjednoczenia mechanizmy rządzące zachodnioniemieckim systemem partyjnym zostały przetransferowane do tzw. nowych krajów federacji, a powstałe podczas demokratyzacji NRD lat 1989/1990 niewielkie ugrupowania wschodnioniemieckie zostały w większości wchłonięte przez swe zachodnioniemieckie odpowiedniki. Do najważniejszych konsekwencji zjednoczenia zaliczyć można: pojawienie się na niemieckiej scenie politycznej nowego ugrupowania (PDS, od 2007 roku Die Linke) reprezentującego przede wszystkim interesy mieszkańców byłej NRD, co w dalszej perspektywie doprowadziło do wykształcenia się na poziomie federalnym systemu pięciu partii; zróżnicowane preferencje wyborcze mieszkańców obu części 
Niemiec (i wyodrębnienie się podsystemu partyjnego dla Niemiec wschodnich); osłabienie po 1990 roku znaczenia obu wielkich partii ogólnospołecznych, a także ograniczenie roli i wpływów FDP. Po 1990 roku, a zwłaszcza po 2005 roku, przyspieszeniu uległa dynamika zmian na niemieckiej scenie politycznej. W efekcie coraz częściej dochodzi do znacznych przeobrażeń na niemieckiej scenie politycznej, pojawiają się nowe ugrupowania będące w stanie w krótkim czasie zyskać znaczące poparcie społeczne dzięki podejmowaniu nośnych tematów będących przedmiotem debaty publicznej, ponadto nastąpiło osłabienie przywiązania wyborców do partii politycznych. Oprócz tego po 2005 roku ograniczone zostało znaczenie dominującego od połowy lat 80 . układu dwublokowego, gdyż w wyniku wyborów do Bundestagu w 2005 i 2013 roku żaden z dotychczasowych bloków nie miał większości i potrzebne były nowe rozwiązania (wielka koalicja). Również na poziomie krajów, w obliczu postępującej fragmentacji systemu partyjnego, coraz trudniej zawiązać jest koalicje w oparciu o dotychczasowe bloki, dlatego pojawiają się nowe rozwiązania, jak np. wielkie koalicje, koalicje CDU i partii Zielonych (Hesja, Badenia-Wirtembergia), czy też koalicje złożone z trzech partii. Dlatego coraz trudniej jest przewidzieć kierunek w jakim ewoluować będzie niemiecki system partyjny w najbliższych latach.

\section{Zusammenfassung}

Der Artikel beschreibt und fasst die Auswirkungen der Wiedervereinigung auf das deutsche Parteiensystem nach 1990 zusammen. Zu den wichtigsten Konsequenzen der Vereinigung gehören: 1) die Entstehung einer neuen Partei (die PDS, seit 2007 Die Linke), welche die Interessen der Ostdeutschen Bevölkerung vertrat; 2) darauffolgende Bildung einer Fünfparteiensystem nach 1990; 3) unterschiedliche Wahlpräferenzen der West- und Ostdeutschen und die Herausbildung eines spezifischen regionalen Parteiensystems in den neuen Bundesländern (das Modell 3+, d.h. CDU, SPD, PSD/Die Linke + eventuell andere Parteien); 4) die Abschwächung beider großen Volksparteien und Verlust ihrer Dominanzposition innerhalb des deutschen Parteiensystems nach der Bundestagswahl 2009; 5) Relevanzverlust der FDP; 6) größere Veränderungsdynamik auf der deutschen politischen Szene.

Das Ergebnis der Bundestagswahlen vom 22. September 2013 brachte große Veränderungen auf der politischen Szene Deutschlands. Beide Volksparteien, insbesondere CDU/CSU, gewannen zum Teil die verlorenen Positionen zurück, hauptsächlich auf Kosten der mittleren Parteien, FDP befand sich zum ersten Mal außer Bundestag und auf der deutschen politischen 
Szene erschien eine neue Partei - AfD. Nach der Wahl entstand das Modell 4+2 (vier Parteien: CDU/CSU, SPD, Die Linke und die Grünen, die im Bundestag vertreten sind + FDP und AfD, die knapp unter Sperrklausel waren) und die Große Koalition von CDU/CSU und SPD übernahm die Macht. Diese Konstellation schien eine Zeit lang beständig zu sein. Dennoch wurde die Position der beiden regierenden Parteien (insbesondere der CDU) seit dem Ausbruch der Migrationskrise abgeschwächt und der Einfluss der AfD, die konsequent gegen die Willkommenspolitik der Bundeskanzlerin Angela Merkel opponieren, wurde allmählich stärker.

\section{Bibliografia}

ALEMANN U., Das Parteiensystem der Bundesrepublik Deutschland, Bonn 2010.

BOJENKO-IZDEBSKA E., „Wschód głosuje inaczej”. Preferencje wyborcze w nowych krajach federacji po 1990 roku, „Przegląd Zachodni” 2014, nr 1.

DITTBERNER J., Die FDP. Geschichte, Personen, Organisation, Perspektiven. Eine Einführung, Wiesbaden 2005.

HOLTMANN E., Der Parteienstaat in Deutschland. Erklärungen, Entwicklungen, Erscheinungsbilder, Bonn 2012.

JESSE E., Nach allen Seiten offen? Der Ausgang der Bundestagswahl 2013 und mögliche Folgen für das Parteiensystem und das Koalitionsgefüge, „Zeitschrift für Politik" 2013, nr 4.

KIRCHHEIMER O., Der Wandel des westeuropäischen Parteiensystems, „Politische Vierteljahresschrift" 1965, nr 1(6).

KLINGEMANN H., KAASE M. (red.), Wahlen und Wähler. Analysen aus Anlaß der Bundestagswahl 1990, Berlin 1994.

KONSTYTUCJA Niemieckiej Republiki Demokratycznej, Berlin 1968.

KORTE K.-R. (red.), Die Bundestagswahl 2009. Analysen der Wahl-, Parteien-, Kommunikations- und Regierungsforschung, Wiesbaden 2010.

KRUK A., Wolna Partia Demokratyczna po zjednoczeniu Niemiec (19902013), Zielona Góra 2015.

KUBIAK P., Przemiany $w$ obrębie niemieckiego systemu partyjnego po 2009 roku, [w:] Polityka - kultura - społeczeństwo. Niemcy, Austria, Szwajcaria w pierwszej dekadzie XXI wieku, E. Kuczyński, M. Tomczyk (red.), Łódź 2013.

KUBIAK P., System partyjny i partie polityczne zjednoczonych Niemiec (19902013), Poznań 2014.

KUBIAK P., Wybory do Bundestagu z 22 września 2013 roku - analiza i konsekwencje, „Przegląd Zachodni” 2014, nr 1. 
LEUSCHNER U., Die Geschichte der FDP. Metamorphosen einer Partei zwischen rechts, sozialliberal und neokonservativ, Münster 2005.

LÖSCHE P., Ende der Volksparteien, „Aus Politik und Zeitgeschichte” 2009, nr 5.

LÖSCHE P., WALTER F., Die SPD. Klassenpartei-Volkspartei-Quotenpartei, Darmstadt 1992.

MALYCHA A., WINTERS P., Geschichte der SED. Von der Gründung bis zur Linkspartei, Bonn 2009.

NIEDERMAYER O. (red.), Handbuch Parteienforschung, Wiesbaden 2013.

NIEDERMAYER O., Halbzeit. Die Entwicklung des Parteiensystems nach der Bundestagswahl 2013, „Zeitschrift für Parlamentsfragen” 2015, nr 4.

RUDZIO W., Das politische System der Bundesrepublik Deutschland, Wiesbaden 2011.

www.forschungsgruppe.de 